\title{
The functional maturation of the Sertoli cell and Leydig cell in the mammalian testis
}

\author{
G. M. H. Waites, Alison C. Speight and N. Jenkins* \\ Department of Physiology \& Biochemistry, University of Reading, P.O. Box 228, Whiteknights, \\ Reading RG6 $2 A J, U . K$.
}

\section{Introduction}

The morphological features and associations of the Sertoli and Leydig cells in the adult have clear implications for their functional characteristics and for their development in the maturing testis. For example, adult Sertoli cells form intimate cellular associations with germ cells through both physical contact and gap junctions with significance for metabolic cooperation between the two cell types. Inter-Sertoli cell junctional specializations are influential in the context of the "blood-testis barrier'. They also establish the polarity of these cells with their basal aspect against a peritubular myoid cell layer and a luminal aspect from which fluid is secreted. Leydig cells are associated with the peritubular myoid cells and with the interstitial blood vessels, being surrounded to varying extents according to species by interstitial spaces and fluid. There is a positive correlation between the amount of testosterone secreted by perfused testes in vitro of various species and the volume of smooth endoplasmic reticulum in their Leydig cells (see Ewing \& Zirkin, 1983). The transport of the secretory products of the Sertoli and Leydig cells depends upon dynamic exchanges with the various fluids secreted by the testis (see reviews by: Waites, 1977; Steinberger \& Steinberger, 1977; Fritz, 1978; Setchell, 1978; Means et al., 1980; Purvis \& Hansson, 1981; Parvinen, 1982; Waites \& Gladwell, 1982; Ritzén \& Syed, 1985; Sharpe, 1984).

Thus, the adult features of the Sertoli and Leydig cells are relevant when considering their functional maturation in the developing testis.

\section{Prenatal development}

The precursor cell types of the Sertoli and Leydig cells appear early in fetal life (see Gondos, 1977). The former are believed to arise from the gonadal blastema and the latter from undifferentiated mesenchymal cells in the interstitium (see Pelliniemi \& Dym, 1980). Thus, sexual differentiation of the male gonad starts with the formation of the testicular or seminiferous cords at 13 days of gestation in the rat (Jost, Magre, Cressent \& Perlman, 1974; Jost, Magre \& Ageloupoulou, 1981), 26 days in the pig (Pelliniemi, 1975; Pelliniemi \& Lauteala, 1981) and 42 days in the human (Pelliniemi \& Dym, 1980).

The testicular cords are believed to be directed by the presence of the $\mathrm{H}-\mathrm{Y}$ antigen and its binding to receptors on the somatic gonadal blastema cells (Wachtel, Ohno, Koo \& Boyse, 1975; Ohno, 1976; Wachtel \& Koo, 1981; Silvers, Gasser \& Eicher, 1982; Gore-Langton, Tung \& Fritz, 1983; see Ritzén \& Syed, 1985). In the pig fetus at 27 days of age testicular cords surround interstitial spaces which contain small, irregularly shaped, undifferentiated cells. Primordial germ cells, while capable of free migration in the open channels of the interstitium, nevertheless associate themselves with the precursor Sertoli cells. The latter have one or two large nucleoli and are the first stage at which antiMüllerian hormone (AMH) activity appears in the pig (Tran, Meusy-Dessolle \& Josso, 1977). By

\footnotetext{
* Present address: Biological Laboratory, University of Kent, Canterbury CT2 7NJ, U.K.
} 
35 days onwards, pig Sertoli cells have a well developed Golgi apparatus and morphologically appear to be well equipped for protein synthesis (van Vorstenbosch, Spek, Colenbrander \& Wensing, 1984).

Steroidogenesis begins in the fetal pig testis at 30-35 days (Raeside \& Sigman, 1975) at which time the interstitial cells have differentiated and contain abundant smooth endoplasmic reticulum (Pelliniemi \& Lauteala, 1981). A similar steroidogenic capacity becomes apparent in the human fetal gonad at 8 weeks (Huhtaniemi, Ikonen \& Vihko, 1970). The proportion of interstitial tissue then increases to a peak at around 12 weeks fetal age and is followed by an involutionary phase (Niemi, Ikonen \& Hervonen, 1967; Pelliniemi \& Niemi, 1969). The stimulation of fetal androgen production is associated with the peak in serum hCG at 12 weeks rather than with LH or FSH secretion which is not detected in human fetal plasma until later (Kaplan, Grumbach \& Aubert, 1976).

Fetal Sertoli cells actively intervene in the organization of the male gonad through the secretion of the glycoprotein AMH early in fetal life, i.e. at 14.5 days in the rat (Picon, 1970; Josso, Picard \& Tran, 1977, 1980). AMH has been localized immunocytochemically in the rough endoplasmic reticulum of the developing bovine Sertoli cell where it is first detectable at $42-43$ days of fetal life and reaches peak concentrations at 50-80 days corresponding with the period of Müllerian duct regression (Vigier, Picard \& Josso, 1982; Vigier, Tran, du Mesnil du Buisson, Heyman \& Josso, 1983; Josso \& Picard, 1985). Recent evidence indicates that AMH dephosphorylates proteins on the plasma membrane of Müllerian duct cells and thus antagonizes the effects of epidermal growth factor (Donahoe, Hutson, Fallat, Kamagata \& Budzik, 1984).

Receptors for $\mathrm{LH}$ are first detected in the rat fetal testis at 15.5 days and achieve maximal concentration at birth (Warren, Huhtaniemi, Tapanainen, Dufau \& Catt, 1984). The binding of FSH in the fetal rat testis increased from about 17.5 days until birth which could be attributed to an increase in the number of FSH receptors per Sertoli cell, an increase in the number of Sertoli cells or to both. Mitosis of Sertoli cells occurs during the growth of the testicular cords (Pelliniemi \& Dym, 1980), during the late fetal period in rats under the influence of FSH (Orth, 1984) and is wellestablished at birth and then declines in early postnatal life (rat: Steinberger \& Steinberger, 1971; Nagy, 1972; lamb: Courot, 1971; Hochereau-de Reviers \& Courot, 1978).

Birth intervenes in the developmental process at different stages in testicular maturation in different species and this should be borne in mind when considering postnatal events.

\section{Postnatal development}

\section{Sertoli cell}

Practically all of the functional characteristics of the Sertoli cell undergo marked changes between birth and puberty. For example, androgen binding protein (ABP) is a well-characterized protein that binds testosterone and $5 \alpha$-dihydrotestosterone with high affinity and is considered to be a postnatal 'marker' for protein secretion by the Sertoli cell and to be under the direct control of FSH (see Means et al., 1980; DePhilip, Feldman, Spruill, French \& Kierszenbaum, 1982). ABP is detectable in fetal rat serum from Day 16 of gestation in both sexes and therefore its prime source at this stage may be the liver (Carreau, Musto, Bercu, Bardin \& Gunsalus, 1985), although a local testicular content of Sertoli cell origin is not ruled out. After birth ABP reappears in the circulation of only male rats and rises sharply to peak values at around 3 weeks. With the formation of the blood-testis barrier and the start of secretion of tubular fluid by the Sertoli cells, ABP is diverted to the epididymis and less appears in the circulation.

Since the early 1970s most of our knowledge concerning the functional maturation of Sertoli cells derives from primary cell culture studies. When cells from rats of about 3 weeks of age are cultured in a defined medium, they secrete several polypeptides, ranging in molecular weight from approximately 16000 to 140000 (Wilson \& Griswold, 1979; Kissinger, Skinner \& Griswold, 1982). 


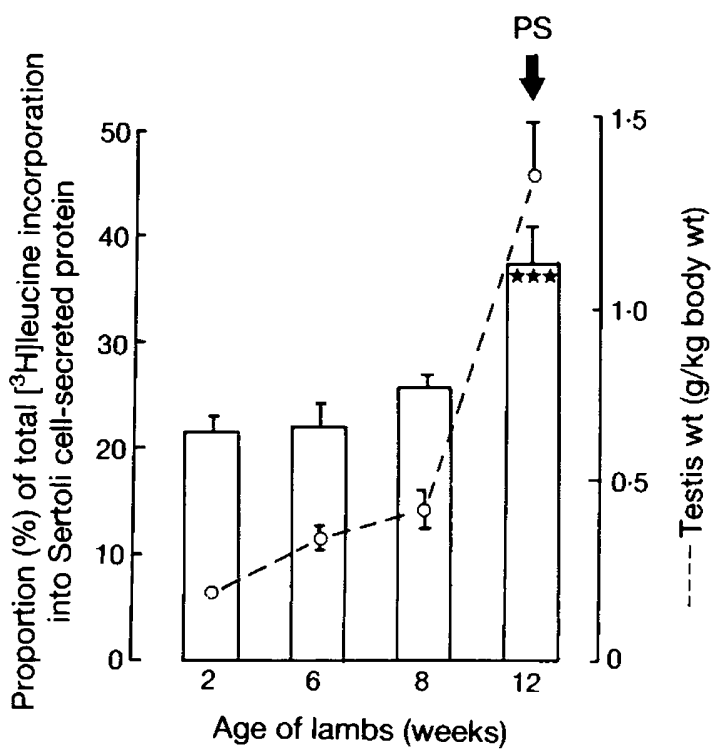

Text-fig. 1. Proportion (\%) of total $\left[{ }^{3} \mathrm{H}\right]$ leucine incorporation into Sertoli cell-secreted proteins. Sertoli cell cultures were prepared from the testes of lambs of 2,6,8 or 12 weeks of age. $\left[{ }^{3} \mathrm{H}\right]$ Leucine was added at Day 6 of culture. After $24 \mathrm{~h}$ its incorporation into cellular and secreted protein was separately determined. Values are mean \pm s.e.m. ${ }^{* * *} P<0.001$ compared to value at 2 weeks. Approximate time of appearance of primary spermatocytes (PS) in the lamb testis.

Amongst these are ABP (Fritz, Kopec, Lam \& Vernon, 1974), plasminogen activator, a tissue protease (Lacroix, Smith \& Fritz, 1977), transferrin and ceruloplasmin, iron and copper transport proteins respectively (Skinner \& Griswold, 1980; Kissinger et al., 1982) and galactosyl transferase, an enzyme involved in the glycosylation of proteins (D. W. Hamilton, personal communication). The patterns of proteins secreted from Sertoli cells obtained from rats at 20 and 60 days of age were similar to each other but differed from those of Sertoli cells from 10-day-old rats (Kissinger et al., 1982). Sertoli cells cultured from lambs at different maturational stages demonstrate a significant age-dependent increase in the proportion of newly synthesized protein for secretion as measured by the incorporation of $\left[{ }^{3} \mathrm{H}\right]$ leucine; protein secretion is increasing at the time when spermatogenesis is starting (Text-fig. 1; Speight, Clifford \& Waites, 1985). Some of the secreted proteins in the rat were shown to arise from peritubular myoid cells. Such cells in co-culture can influence the efficiency of ABP secretion by Sertoli cells (Tung \& Fritz, 1980; Hutson \& Stocco, 1981) and act co-operatively with Sertoli cells to synthesize the various components of the extracellular matrix of the basal lamina (Fritz, 1985).

In most mammalian species, Sertoli cells spend long periods associated with only one germ cell type, the pre-spermatogonium, e.g. lamb (3-4 months; Courot, 1971), pig (3-4 months; Peyrat, Meusy-Desolle \& Garnier, 1981), human (10-12 years; Camatini, Franchi, de-Curtis, Anelli \& Masera, 1982), whereas the Sertoli cell of the rat becomes associated with proliferating germ cells within hours of birth. An age-dependent secretion of lactate and pyruvate by rat Sertoli cells has been shown (Jutte, Jansen, Grootegoed, Rommerts \& van der Molen, 1983): lactate production was stimulated by added FSH and testosterone, and the effect was most pronounced at 4 weeks of age (Text-fig. 2a). Additional stimulation was also elicited by insulin (Oonk, Grootegoed, Reuvers $\&$ van der Molen, 1985). Spent medium from cultured Sertoli cells from 4-week-old rats stimulated leucine incorporation into isolated germ cells, an effect which could be accounted for by the amounts of pyruvate and lactate present (Text-fig. 2b; Jutte et al., 1982, 1983). These products of 

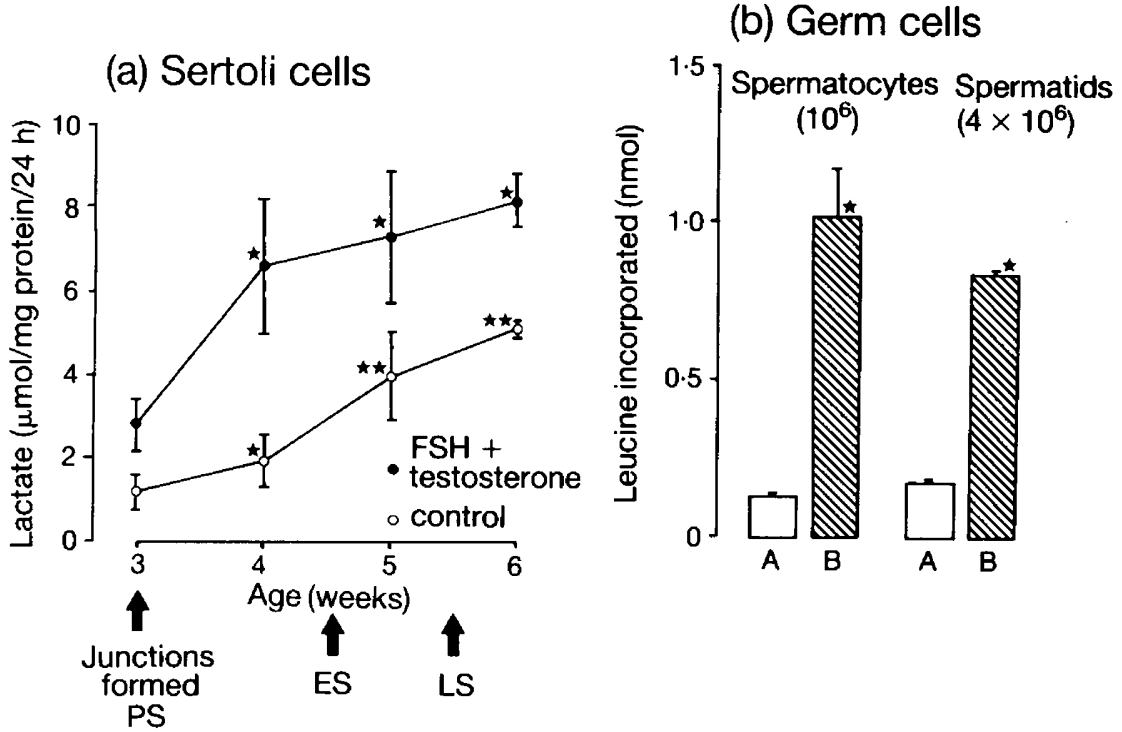

Text-fig. 2. The potential support of germ cell function by Sertoli cell products of glycolysis (data from Jutte et al., 1983). (a) Sertoli cells from prenatally irradiated rats incubated for $24 \mathrm{~h}$ in medium without hormones $(O)$ or with added FSH $(7.5 \mathrm{NIH}-\mathrm{FSH}-\mathrm{S} 1 \mathrm{U} / \mathrm{ml})$ and testosterone $(200 \mathrm{ng} / \mathrm{ml})(\odot) .{ }^{*} P<0.05$ compared to value at 3 weeks; ${ }^{* *} P<0.05$ compared to value at 4 weeks. Approximate time of appearance of primary spermatocytes (PS), early and late spermatids (ES, LS) in the rat testis. (b) Stimulatory effect of leucine incorporation into germ cells of spent medium from FSH + testosterone stimulated Sertoli cells from 4-week-old rats (B) compared to fresh medium (A). ${ }^{*} P<0.01$ compared to value for $\mathrm{A}$.

glycolysis have also been shown to increase ATP levels in isolated round spermatids (Mita \& Hall, 1982). It is suggested, therefore, that germ cells may depend upon Sertoli cells for their metabolic support.

Several of the activities of the Sertoli cell are stimulated by FSH especially in the immature animal. The number of FSH receptors increases slowly until approximately 80 days of age in the lamb (Barenton, Hochereau-de Reviers, Perreau \& Saumande, 1983), in association with increasing numbers of Sertoli cells during this period (Courot, 1962). Thereafter sharp increases in the number of both LH and FSH receptors coincide with the onset of spermatogenesis.

\section{Leydig cell}

In most mammalian species, the high plasma testosterone concentrations achieved shortly after birth decline and remain low until just before puberty (Ewing \& Zirkin, 1983). The concentration of LH receptors, expressed as moles per mg testicular protein declines postnatally in the lamb and pig (Barenton et al., 1983; Sundby, Torjesen \& Hansson, 1983). This change may be due in part to the differential growth of the tubular and interstitial elements within the testis (Waites, Wenstrom, Crabo \& Hamilton, 1983), although atrophy of a proportion of the Leydig cell population has been observed during this period in rats (Lee \& Burger, 1983). The concentration of LH receptors remains constant during the first 5 days of life in rats yet the testosterone concentrations within the testis decline rapidly (Warren et al., 1984).

Several steroidogenic enzymes display age-dependent activities which do not parallel the numbers of Leydig cells in the testis (Preslock, 1980; Payne, Chase \& O'Shaughnessy, 1982). The activity of $5 \alpha$-reductase in rats reaches a peak at 15-20 days of age and results in an abundance of 
hCG-provoked testosterone secretion (ng/106 cells $/ 4 \mathrm{~h}$ )

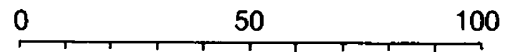
Leydig cells
alone

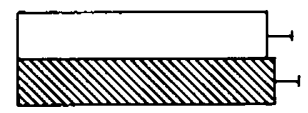

Binding of ${ }^{125}$-labelled hCG

(c.p.m. $\times 10^{3} / 10^{6}$ cells)
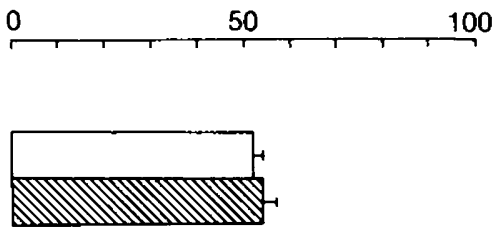

$\left[\begin{array}{l}\text { n.d. } \\ \text { n.d. }\end{array}\right.$

\section{Leydig +}

Sertoli cells
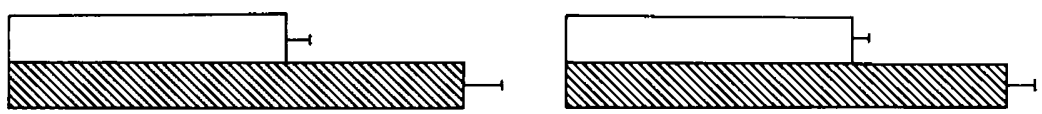

Text-fig. 3. The augmentation by porcine FSH $(50 \mathrm{ng} / \mathrm{ml})$ of binding of ${ }^{125} \mathrm{I}$-labelled hCG and of hCG-provoked testosterone secretion by the Leydig cells of 3-week-old pigs when cocultured with Sertoli cells (adapted from the data of Reventos et al., 1983). nd = undetectable.

$5 \alpha$-reduced androgens in plasma and a paucity of testosterone. Another example of altered steroidogenesis in early postnatal life is the change in the ratio of androstenedione to testosterone which occurs during the prepubertal period in the bull (Lindner, 1969).

The increasing plasma concentrations of LH during puberty result in an increase in the number of active Leydig cells with parallel elevations in the testicular content of the steroidogenic enzymes $17 \alpha$-hydroxylase, C17-20 lyase and $\Delta_{5}-3 \beta$-hydroxysteroid dehydrogenase-isomerase (Payne et al., 1982), suggesting that the activities of these enzymes within each Leydig cell do not change during development. Controversy surrounds the question of whether there are one or two different functional populations of Leydig cells (Payne et al., 1982), an issue which may relate to the method used to separate the cells (Aquilano \& Dufau, 1984).

The activity of aromatase (a multi-enzyme complex which converts androgens to oestrogens) in rat Sertoli cells declines during puberty while at the same time it increases in the Leydig cells (Rommerts, de Jong, Brinkmann \& van der Molen, 1982; see Ritzén \& Syed, 1985). Despite this, the total production of oestrogen remains at $<0.1 \%$ of androgen output in most mammalian species, with the exception of the stallion and boar (Amann \& Schanbacher, 1983). Implants of oestradiol depress plasma androgen concentrations in lambs (Jenkins \& Waites, 1983), and conversely immunization against oestradiol stimulates androgen production in rats (Nishihara \& Takahashi, 1983) and lambs (N. Jenkins, P. G. Knight, C. M. Howles, B. A. Morris \& G. M. H. Waites, unpublished observations). Studies in vitro, however, suggest that although the Leydig cells of neonatal animals have oestrogen receptors (Brinkmann, Mulder, Lamerstahlhofen, Mechielsen \& van der Molen, 1972; Moger, 1980; Benahmed, Bernier, Ducharme \& Saez, 1982), the concentrations of oestradiol required to impair the steroidogenic function of Leydig cells directly are probably never achieved in vivo, and therefore a suppression of $\mathrm{LH}$ secretion is a more likely explanation of the effects of oestradiol on androgen production.

\section{Inter-cellular communication}

The co-culture of pig Leydig with Sertoli cells has shown that FSH, acting via the Sertoli cell, stimulates the secretion of testosterone by the Leydig cells (Text-fig. 3; Reventos, Benahmed, 

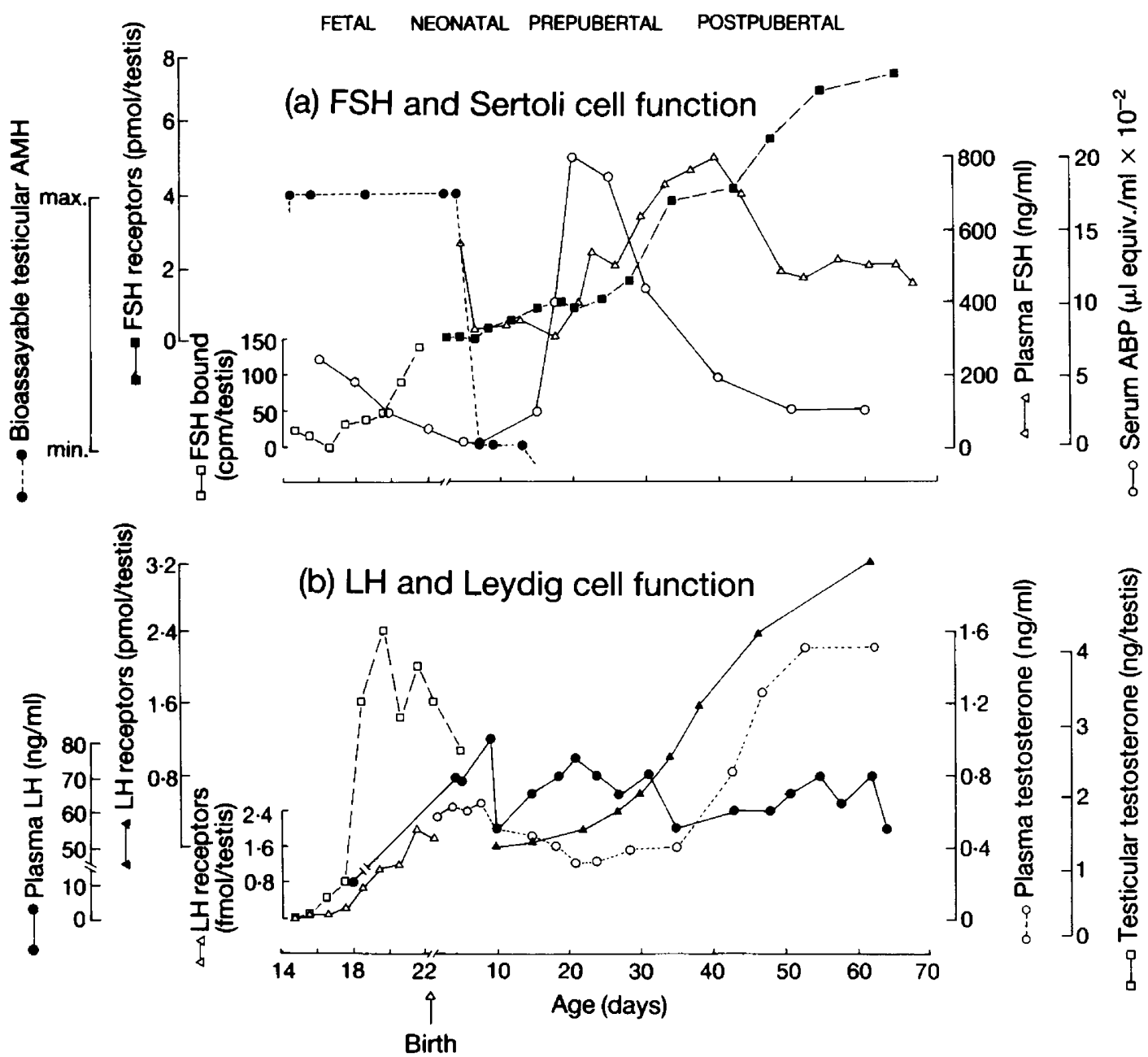

Text-fig. 4. Age-dependent changes in plasma FSH and LH concentrations and some associated functions of Sertoli and Leydig cells in the rat. (a) Testicular FSH receptors, expressed as FSH bound (c.p.m.) per testis for fetal values (data from Warren et al., 1984) and as pmol per testis for postnatal values (data from Ketelslegers, Hetzel, Sherins \& Catt, 1978) are compared with postnatal plasma FSH concentrations (data from Ketelslegers et al., 1978). Bioassayable testicular AMH was detectable at Day 14.5 of fetal life and remained at a similar concentration until Day 4 after birth and subsequently declined (data from Picon, 1970). Serum ABP concentrations declined during fetal life, reflecting decreased synthesis in the liver, and increased after birth due to increased synthesis by the Sertoli cell; the subsequent decline corresponds to the establishment of the blood-testis barrier and the excretion of ABP towards the epididymis (data from Carreau et al., 1985). (b) Testicular LH receptors expressed as fmol per testis for fetal values (data from Warren et al., 1984) and as pmol per testis for postnatal values (data from Ketelslegers et al., 1978) are compared with postnatal plasma LH concentrations (data from Ketelslegers et al., 1978). Testicular testosterone was detectable from Day 15.5 of fetal life and increased to a maximum concentration by Day 18.5 and remained at a similar concentration through birth but decreased by Day 5 after birth (data from Warren et al., 1984). Plasma testosterone concentration was elevated 2-8 days after birth and then declined to remain low until Days 35-55 when a rapid increase was observed, starting about 15 days after the onset of the increase in LH receptors (data from Ketelslegers $e t$ al., 1978). 
Tabone \& Saez, 1983). The chemical nature of the messengers which may mediate Sertoli-Leydig cell communication remains uncertain, although evidence confined to rats has identified a gonadotrophin-releasing hormone-like peptide in Sertoli cell secretions which binds to receptors on the Leydig cells (Sharpe, 1982, 1984). Prolactin has been shown to induce Leydig cell receptors for LH, but its role in testicular maturation remains ill-defined (Payne et al., 1982).

The compensatory changes that follow hemicastration in the prepubertal period may provide insights into the mechanisms of normal testicular development. Most studies indicate that FSH secretion is increased by neonatal hemicastration and, in lambs, is secondarily suppressed back to control levels at 8-10 weeks of age, i.e. before the onset of spermatogenesis (Walton, Evins, Hillard \& Waites, 1980; Waites et al., 1983). It was postulated that this FSH modulation might be a manifestation of 'inhibin' secretion by the FSH-stimulated prepubertal Sertoli cell of the lamb as previously suggested for the rat (Steinberger, 1979). Another feature of the response to hemicastration in rats, lambs, and bulls is the maintenance of normal plasma androgen concentrations despite the loss of steroidogenic tissue and any compensation which might occur through an increase in Leydig cell numbers (Cunningham, Tindall, Huckins \& Means, 1978; Barnes, Longnecker, Reisen \& Woody, 1980; Jenkins, Speight \& Waites, 1985). The altered androgen production may be stimulated indirectly by the FSH acting on Sertoli cells since an increase in LH secretion in response to hemicastration is less evident. The sensitivity of Leydig cells to LH is increased after hemicastration in bulls (Boockfor, Barnes \& Dickey, 1983) but not in lambs (Jenkins \& Waites, 1983).

\section{Conclusion}

There is clear evidence, therefore, that the Sertoli cell and the Leydig cell exhibit specific functional activities at different stages in their maturation (Text-fig. 4). It is less clear how the age-dependent development of the two cell types is interrelated and co-ordinated. The 'signals' that pass between these cells are likely to be steroid from the Leydig cells and predominantly peptide from the Sertoli cells, but how these signals are initiated or modulated remains unknown. Co-culture experiments are beginning to yield some information, but ultimately, an intimate understanding of testicular maturation in terms of co-ordinated cell-cell interactions will need elucidation in the intact animal.

Research from our laboratory referred to in this review has been supported by grants from the U.K. Agricultural \& Food Research Council (Nos AG45/192, AG45/211 and AG45/229) and N.A.T.O. (No. 241/80).

\section{References}

Amann, R.P. \& Schanbacher, B.D. (1983) Physiology of male reproduction. J. Anim. Sci. 57. Suppl. 2, $380-402$.

Aquilano, D.R. \& Dufau, M.L. (1984) Functional and morphological studies on isolated Leydig cells: purification by centrifugal elutriation and Metrizamide fractionation. Endocrinology 114, 499-510.

Barenton, B., Hochereau-de Reviers, M.T., Perreau, C. \& Saumande, J. (1983) Changes in testicular gonadotrophin receptors and steroid content through postnatal development until puberty in the lamb. Endocrinology 112, 1447-1453.

Barnes, M.A., Longnecker, J.V., Reisen, J.W. \& Woody, C.O. (1980) Influence of unilateral castration and increased plane of nutrition on sexual development of Holstein bulls. III. Endocrine responses. Theriogenology 14, 67-81.

Benahmed, M., Bernier, M., Ducharme, J.R. \& Saez, J.M. (1982) Steroidogenesis of cultured purified pig Leydig cells: secretion and effects of estrogens. Molec. cell. Endocr. 28, 705-716.

Brinkmann, A.O., Mulder, E., Lamerstahlhofen, G.J.M., Mechieisen, N.J. \& van der Molen, H.J. (1972) Binding of oestradiol by the nuclear fraction of rat testis interstitial tissue. FEBS Lett. 26, 301-305.

Boockfor, F.R., Barnes, M.A. \& Dickey, J.F. (1983) Effects of unilateral castration and unilateral cryptorchidism of the Holstein bull on in vitro Leydig cell response. J. Anim. Sci. 56, 1386-1392.

Camatini, M., Franchi, E., de-Curtis, I., Anelli, G. \& 
Masera, G. (982) Chemotherapy does not affect the development of inter-Sertoli junctions in childhood leukaemia. Anat. Rec. 203, 353-363.

Carreau, S., Musto, N.A., Bercu, B.B., Bardin, C.W. \& Gunsalus, G.L. (1985) The androgen binding protein as an index of the rat Sertoli cell function. In Recent Progress in Cellular Endocrinology of the Testis, pp. 157-161. Eds J. M. Saez, M. G. Forest, A. Dazord \& J. Bertrand. INSERM, Paris.

Courot, M. (1962) Développement du testicule chez l'Agneau. Etablissement de la spermatogénèse. Annls Biol. anim. Biochim. Biophys. 2, 25-42.

Courot, M. (1971) Etablissement de la spermatogénèse - chez l'agneau (Ovis Aries); Etude expérimentale de son contrôle gonadotrope; importance des cellules de la lignée Sertolienne. D.Sc. thèse, Paris.

Cunningham, G.R., Tindall, D.J., Huckins, C. \& Means, A.R. (1978) Mechanisms for the testicular hypertrophy which follows hemicastration. Endocrinology 102, 16-22.

DePhilip, R.M., Feldman, M., Spruill, W.A., French, F.S. \& Kierszenbaum, A.L. (1982) The secretion of androgen-binding protein and other proteins by rat Sertoli cells in culture: a structural and electrophoretic study. Ann. N.Y. Acad. Sci. 383, 360-371.

Donahoe, P.K., Hutson, J.M., Fallat, M.E., Kamagata, S. \& Budzik, G.P. (1984) Mechanism of action of Müllerian inhibiting substance. Ann. Rev. Physiol. 46, 53-65.

Ewing, L.L. \& Zirkin, B. (1983) Leydig cell structure and steroidogenic function. Recent Prog. Horm. Res. 39, 599-635.

Fritz, I.B. (1978) Sites of action of androgens and follicle stimulating hormone on cells of the seminiferous tubule. In Biochemical Actions of Hormones, Vol. V, pp. 249-281. Ed. G. Litwack. Academic Press, New York.

Fritz, I.B. (1985) Past, present and future of molecular and cellular endocrinology of the testis. In Recent Progress in Cellular Endocrinology of the Testis, pp. 15-54. Eds J. M. Saez, M. G. Forest, A. Dazord \& $J$. Bertrand. INSERM, Paris.

Fritz, I.B., Kopec, B., Lam, K. \& Vernon, R.G. (1974) Effects of FSH on levels of androgen binding protein in the testis. In Hormone Binding and Target Cell Activation in the Testis, pp. 311-327. Eds M. L. Dufau \& A, R. Means. Plenum Press, New York.

Gondos, B. (1977) Testicular development. In The Testis, Vol. 4, pp. I-37. Eds A. D. Johnson \& W. R. Gomes. Academic Press, New York.

Gore-Langton, R.E., Tung, P.S. \& Fritz, I.B. (1983) The absence of specific interactions of Sertoli-cell-secreted proteins with antibodies directed against $\mathrm{H}-\mathrm{Y}$ antigen. Cell 32, 289-301.

Hochereau-de Reviers, M.T. \& Courot, M. (1978) Sertoli cells and development of seminiferous epithelium. Annls Biol. anim. Biochim. Biophys. 18, 573-583.

Huhtaniemi, I., Ikonen, M. \& Vihko, R. (1970) Presence of testosterone and other neutral steroids in human fetal testis. Biochem. Biophys. Res. Commun. 38, $715-720$.

Hutson, J.C. \& Stocco, D.M. (1981) Peritubular cell influence of the efficiency of androgen-binding protein secretion by Sertoli cells in culture. Endocrinology 108, 1362-1368.
Jenkins, N. \& Waites, G.M.H. (1983) Effects of hemicastration at various ages and of oestradiol- $17 \beta$ on plasma concentrations of gonadotrophins and androgens, testicular growth and interstitial cell responses in prepubertal lambs. J. Reprod. Fert. 67, 325-334.

Jenkins, N., Speight, A. \& Waites, G.M.H. (1985) Short term hormone changes following the removal of one or both testes in the lamb. In Recent Progress in Cellular Endocrinology of the Testis, pp. 347-351. Eds J. M. Saez, M. G. Forest, A. Dazord \& J. Bertrand. INSERM, Paris.

Josso, N. \& Picard, J-Y. (1985) Anti-Mullerian hormone. Physiol. Rev. (In press.)

Josso, N., Picard, J-Y. \& Tran, D. (1977) The antiMüllerian hormone. Recent Prog. Horm. Res. 33, $17-163$.

Josso, N., Picard, J-Y. \& Tran, D. (1980) A new testicular glycoprotein: anti-Müllerian hormone. In Testicular Development, Structure, and Function, pp. 21-31. Eds A. Steinberger \& E. Steinberger. Raven Press, New York.

Jost, A., Magre, S., Cressent, M. \& Perlman, S. (1974) Sertoli cells and early testicular differentiation. In Male Fertility and Sterility, pp. 1-11. Eds R. E. Mancini \& L. Martini. Academic Press, London.

Jost, A., Magre, S. \& Ageloupoulou, R. (1981) Early stages of testicular differentiation in the rat. Hum. Genet. 58, 59-63.

Jutte, N.H.P.M., Jansen, R., Grootegoed, J.A., Rommerts, F.F.G., Clausen, O.P.F. \& van der Molen, H.J. (1982) Regulation of survival of rat pachytene spermatocytes by lactate supply from Sertoli cells. $J$. Reprod. Fert. 65, 431-438.

Jutte, N.H.P.M., Jansen, R., Grootegoed, J.A., Rommerts, F.F.G. \& van der Molen, H.J. (1983) FSH stimulation of the production of pyruvate and lactate by rat Sertoli cells may be involved in hormonal regulation of spermatogenesis. J. Reprod. Fert. 68, 219-226.

Kaplan, S.L., Grumbach, M.M. \& Aubert, M.L. (1976) The ontogenesis of pituitary hormones and hypothalamic factors in the human fetus: maturation of central nervous system regulation of anterior pituitary function. Recent Prog. Horm. Res. 32, 161-243.

Ketelslegers, J.-M., Hetzel, W.D., Sherins, R.J. \& Catt, K.J. (1978) Developmental changes in testicular gonadotrophin receptors: plasma gonadotrophins and plasma testosterone in the rat. Endocrinology 103, 212-222.

Kissinger, C., Skinner, M.K. \& Griswold, M.D. (1982) Analysis of Sertoli cell-secreted proteins by twodimensional gel electrophoresis. Biol. Reprod. 27, 233-240.

Lacroix, M., Smith, F.E. \& Fritz, I.B. (1977) Secretion of plasminogen activator by Sertoli cell enriched cultures. Molec. cell. Endocr. 9, 227-236.

Lee, V.W.K. \& Burger, H.G. (1983) Pituitary testicular axis during pubertal development. In The Pituitary and Testis (Monographs on Endocrinology No. 25), pp. 44-70. Eds D. M. de Kretser, H. G. Burger \& B. Hudson. Springer-Verlag, Berlin.

Lindner, H.R. (1969) The androgenic secretion of the testis in domestic ungulates. In The Gonads, pp. 615-648. Ed. K. W. MacKerns. Appleton, New York. 
Means, A.R., Dedman, J.R., Tash, J.S., Tindall, D.J., van Sickle, M. \& Welsh, M.J. (1980) Regulation of the testis Sertoli cell by follicle stimulating hormone. Ann. Rev. Physiol. 42, 59-70.

Mita, M. \& Hall, P.F. (1982) Metabolism of round spermatids from rats: lactate as the preferred substrate. Biol. Reprod. 26, 445-455.

Moger, W.H. (1980) Direct effects of estrogens on the endocrine function of the mammalian testis. Can. $J$. Physiol. Pharmacol. 58, 1011-1022.

Nagy, F. (1972) Cell division kinetics and DNA synthesis in immature Sertoli cells of the rat testis. $J$. Reprod. Fert. 28, 389-395.

Niemi, M., Ikonen, M. \& Hervonen, A. (1967) Histochemistry and fine structure of the interstitial tissue in the human foetal testis. In Endocrinology of the Testis (Ciba Fdn Colloq. Endocrinol.), Vol. 16, pp. 31-55. J. \& A. Churchill Ltd, London.

Nishihara, M. \& Takahashi, M. (1983) Effects of active immunization against estradiol-17 $\beta$ on luteinizing hormone and testosterone in male rats. Biol. Reprod. 29, 1092-1097.

Ohno, S. (1976) Major regulatory genes for mammalian sexual development. Cell 7, 315-321.

Oonk, R.B., Grootegoed, J.A., Reuvers, P.J. \& van der Molen, H.J. (1985) Effects of follitropin (FSH) and insulin on glucose metabolism by Sertoli cells. In Recent Progress in Cellular Endocrinology of the Testis, pp. 193-198. Eds J. M. Saez, M. G. Forest, A. Dazord \& J. Bertrand. INSERM, Paris.

Orth, J.M. (1984) The role of follicle-stimulating hormone in controlling Sertoli cell proliferation in testes of fetal rats. Endocrinology 115, 1248-1255.

Parvinen, M. (1982) Regulation of the seminiferous epithelium. Endocr. Reviews 3, 404-417.

Payne, A.H., Chase, D.J. \& O'Shaughnessy, P.J. (1982) Regulation of steroidogenesis in Leydig cells. In Cellular Regulation of Secretion and Release, pp. 355-408. Ed. P. M. Conn. Academic Press, New York.

Pelliniemi, L.J. (1975) Ultrastructure of the early ovary and testis in pig embryos. Am.J. Anat. 144, 89-111.

Pelliniemi, L.J. \& Dym, M. (1980) The fetal gonad and sexual differentiation. In Fetal-Maternal Endocrinology, pp. 252-280. Eds D. Tulchinsky \& K. Ryan. W. B. Saunders \& Co., Philadelphia.

Pelliniemi, L.J. \& Lauteala, L. (1981) Development of sexual dimorphism in the embryonic gonad. Hum. Genet. 58, 64-67.

Pelliniemi, L.J. \& Niemi, M. (1969) Fine structure of the human foetal testis. Z. Zellforsch. mikrosk. Anat. 99, 507-522.

Peyrat, J.-P., Meusy-Dessolle, N. \& Garnier, J. (1981) Changes in Leydig cells and luteinizing hormone receptors on porcine testis during postnatal development. Endocrinology 108, 625-631.

Picon, R. (1970) Modifications, chez le rat, au cours du developpement du testicule, de son action inhibitrice sur les canaux de Muller in vito. C. r. hebd. Séanc. Acad. Sci., Paris D 271, 2370-2372.

Preslock, J.P. (1980) Steroidogenesis in the mammalian testis. Endocr. Reviews 1, 132-139.

Purvis, K. \& Hansson, V. (1981) Hormonal regulation of spermatogenesis. Int. J. Androl., Suppl. 3, 81-143.

Raeside, J. \& Sigman, D. (1975) Testosterone levels in early fetal testes of domestic pigs. Biol. Reprod. 13 318-321.

Reventos, J., Benahmed, M., Tabone, E. \& Saez, J.M. (1983) Modulation de l'activité de la cellule de Leydig par la cellule de Sertoli: etude in vitro. C. $r$. hebd. Séanc. Acad. Sci., Paris D 296, $123-126$.

Ritzén, E.M. \& Syed, V. (1985) Differentiation and maturation of Sertoli cells: Biochemical aspects. In Recent Progress in Cellular Endocrinology of the Testis, pp. 141-155. Eds J. M. Saez, M. G. Forest, A. Dazord \& J. Bertrand. INSERM, Paris.

Rommerts, F.F.G., de Jong, F.H., Brinkmann, A.O. \& van der Molen, H.J. (1982) Development and cellular localization of rat testicular aromatase activity. $J$. Reprod. Fert. 65, 281-288.

Setchell, B.P. (1978) The Mammalian Testis. Elek Books, London.

Sharpe, R.M. (1982) Cellular aspects of the inhibitory actions of LH-RH on the ovary and testis. J. Reprod. Fert. 64, 517-527.

Sharpe, R.M. (1984) Intratesticular factors controlling testicular function. Biol. Reprod. 30, 2949.

Silvers, W.K., Gasser, D.L. \& Eicher, E.M. (1982) H-Y antigen, serologically detectable male antigen and sex determination. Cell 28, 439-440.

Skinner, M.K. \& Griswold, M.D. (1980) Sertoli cells synthesize and secrete transferrin-like protein. $J$. biol. Chem. 255, 9523-9525.

Speight. A.C., Clifford, J.M. \& Waites, G.M.H. (1985) Protein synthesis by cultured Sertoli cells isolated from prepubertal lamb testes. In Recent Progress in Cellular Endocrinology of the Testis, pp. 199-204. Eds J. M. Saez, M. G. Forest, A. Dazord \& J. Bertrand. INSERM, Paris.

Steinberger, A. (1979) Inhibin production by Sertoli cells in culture. J. Reprod. Fert., Suppl. 26, 31-45.

Steinberger, A. \& Steinberger, E. (1971) Replication pattern of Sertoli cells in maturing rat testis in vivo and in organ culture. Biol. Reprod. 4, 84-87.

Steinberger, A. \& Steinberger, E. (1977) The Sertoli cells In The Testis, Vol. 4, pp. 371-399. Eds A. D. Johnson \& W. R. Gomes. Academic Press, New York.

Sundby, A., Torjesen, P. \& Hansson, V. (1983) Developmental pattern and sensitivity to down-regulation of testicular LH receptors in the pig. Int. J. Androl. 6, 194-200.

Tran, D., Meusy-Dessolle, N. \& Josso, N. (1977) AntiMüllerian hormone is a functional marker of foetal Sertoli cells. Nature, Lond. 269, 411-412.

Tung, P.S. \& Fritz, I.B. (1980) Interactions of Sertoli cells with myoid cells in vitro. Biol. Reprod. 23, 207-217.

van Vorstenbosch, C.J.A.H.V., Spek, E., Colenbrander, B. \& Wensing, C.J.G. (1984) Sertoli cell development of pig testis in the fetal and neonatal period. Biol. Reprod. 31, 565-577.

Vigier, B., Picard, J.Y. \& Josso, N. (1982) A monoclonal antibody against bovine anti-Müllerian hormone. Endocrinology 110, 131-137.

Vigier, B., Tran, D., du Mesnil du Buisson, F., Heyman, Y. \& Josso, N. (1983) Use of monoclonal antibody techniques to study the ontogeny of bovine antiMüllerian hormone. J. Reprod. Fert. 69, 207-214.

Wachtel, S.S. \& Koo, G.C. (1981) H-Y antigen in gonadal differentiation. In Mechanisms of Sex 
Differentiation in Animals and Man, pp. 255-299. Eds C. R. Austin \& R. G. Edwards. Academic Press, London.

Wachtel, S.S., Ohno, S., Koo, G.C. \& Boyse, E.A. (1975) Possible role for $\mathrm{H}-\mathrm{Y}$ antigen in the primary determination of sex. Nature, Lond. 257, 235-236.

Waites, G.M.H. (1977) Fluid secretion. In The Testis, Vol. 4, pp. 91-123. Eds A. D. Johnson \& W. R. Gomes. Academic Press, New York.

Waites, G.M.H. \& Gladwell, R.T. (1982) Physiological significance of fluid secretion in the testis and bloodtestis barrier. Physiol. Rev. 62, 624-671.

Waites, G.M.H., Wenstrom, J.C., Crabo, B.J. \& Hamilton, D.W. (1983) Rapid compensatory hypertrophy of the lamb testis after neonatal hemiorchidectomy: endocrine and light microscopical morphometric analyses. Endocrinology 112, 2159-2167.
Walton, J.S., Evins, J.D., Hillard, M.A. \& Waites, G.M.H. (1980) Follicle-stimulating hormone release in hemicastrated prepubertal rams and its relationship to testicular development. J. Endocr. 84, $141-152$.

Warren, D.W., Huhtaniemi, I.T., Tapanainen, J., Dufau, M.L. \& Catt, K.J. (1984) Ontogeny of gonadotropin receptors in the fetal and neonatal rat testis. Endocrinology 114, 470-476.

Wilson, R.M. \& Griswold, M.D. (1979) Secreted proteins from rat Sertoli cells. Expl Cell Res. 123, 127-135.

Received 4 April 1985 